J. Clin. Chem. Clin. Biochem.

Vol. 20, 1982, pp. 65-68

\title{
Determination of the Psychostimulants Pemoline, Fenozolone and Thozalinone in Human Urine by Gas Chromatography/Mass Spectrometry and Thin Layer Chromatography
}

\author{
By W. Gielsdorf
}

Direktion Polizeitechnische Untersuchungen Berlin (West)

(Received June 26/September 21, 1981)

Summary: Detection of the psychostimulants pemoline $\left(\right.$ Tradon $^{\circledR}$ ), fenozolone (Ordinator ${ }^{\circledR}$ ) and thozalinone (Stimsen ${ }^{\circledR}$ ) in biological samples (urine) presents certain experimental difficulties.

These substances were therefore converted by acid hydrolysis to their common hydrolysis product 5-phenyl-2,4oxazolidinedione, which can be detected with high sensitivity and selectivity by thin layer chromatography.

After silylation with $\mathrm{N}$-methyl-N-trimethylsilyltrifluoroacetamide/trimethylchlorosilane quantitative results can be obtained from the same extract by the proposed GC/MS-method. After a single dose of $30 \mathrm{mg}$ pemoline, levels ranging from one to four $\mathrm{mg} / \mathrm{l}$ urine were observed.

Nachweis der Psychostimulantien Pemoline, Fenozolone und Thozalinone im menschlichen Harn mit Gaschromatographie/Massenspektrometrie und Dünnschichtchromatographie

Zusammenfassung: Der Nachweis der Psychostimulantien Pemoline (Tradon ${ }^{\circledR}$ ), Fenozolone (Ordinator ${ }^{\circledR}$ ) und Thozalinone (Stimsen ${ }^{\circledR}$ ) im biologischen Material (Urin) bietet einige experimentelle Schwierigkeiten.

Daher wurden diese Verbindungen durch salzsaure Hydrolyse quantitativ in das 5-Phenyl-2,4-oxazolidindion umgewandelt, welches sehr empfindlich und selektiv dünnschichtchromatographisch nachgewiesen werden kann. Nach Silylierung mit N-Methyl-N-trimethylsilyltrifluoracetamid/Trimethylchlorsilan können quantitative Ergebnisse mit Hilfe der hier vorgestellten GC/MS-Methode erzielt werden.

Nach einmaliger Einnahme von $30 \mathrm{mg}$ Pemöline konnten so Werte zwischen ein und vier $\mathrm{mg} / \mathrm{l} \mathrm{im}$ Harn gemessen werden.

\section{Introduction}

For some years, the abuse of pemoline $\left.\left(1 ; \text { Tradon }^{\circledR}\right)^{1}\right)$ and its use as a doping agent $(1-6)$ have been a cause for concern. Pemoline and its closely related derivatives, fenozolone (II; Ordinator $\left.{ }^{\circledR}\right)^{2}$ ) and thozalinone (III; Stimsen $\left.{ }^{\circledR}\right)^{3}$ ) are used medically as psychostimulants and antidepressants.

- Chemically they are 5-phenyl-4-oxazolidinones:

I = 2-imino-4-oxo-5-phenyloxazolidine,

II = 2-ethylamino-5-phenyl-4-oxo-2-oxazoline and III = 2-dimethylamino-5-phenyl-4-oxo-2-oxazoline.

\footnotetext{
1) Beiersdorf, Hamburg

2) Lab. Dausse, Paris

3) Lederle, Pearl River, N. Y.
}

Pemoline was synthesized by Traube \& Ascher in 1913 (7); since then, many of its derivatives and analogs have been synthesized and thoroughly tested for their pharmacological activities $(8,9)$. Their detection in human urine is difficult because of their poor extraction and (gas-) chromatographic properties. GC-methods have been published for I (10), but these include extensive, time consuming preparations, e.g. special sample cleanup, involving conversion to benzaldehyde by oxidative degradation (11), or formation of derivatives $(1,2)$.

Other analytical approaches, e.g. paper-chromatography (12), TLC $(4,13)$, microsublimation (14), polarography (15), UV-spectroscopy $(4,11)$ and HPLC (16) are not specific and sensitive enough for determinations in biological fluids and/or not applicable for rapid screening procedures. 
To overcome these obstacles, an efficient screening procedure for the routine assay of pemoline misused in sports has been evaluated by quantitative estimation of its metabolite mandelic acid (5) by mass fragmentography (6). The main drawback of this method is the fact that a high mandelic acid level alone does not fulfill the requirements for a positive identification, since mandelic acid is also a metabolite of other drugs and some drug preparations contain mandelic acid esters as an active constituent.
The GC-methods of Vermeulen, de Roode \& Breimer (1) and van Boven \& Daenens (2) seem to be more practical but include the use of diazomethane, whose dangerous chemical/biological properties prohibit its wide application for routine purposes. In this paper a similar method is presented which allows the simultaneous determination of these three drugs in urine via their common hydrolysis product 5-phenyd $72,4-$ oxazolidinedione (fig. 1):

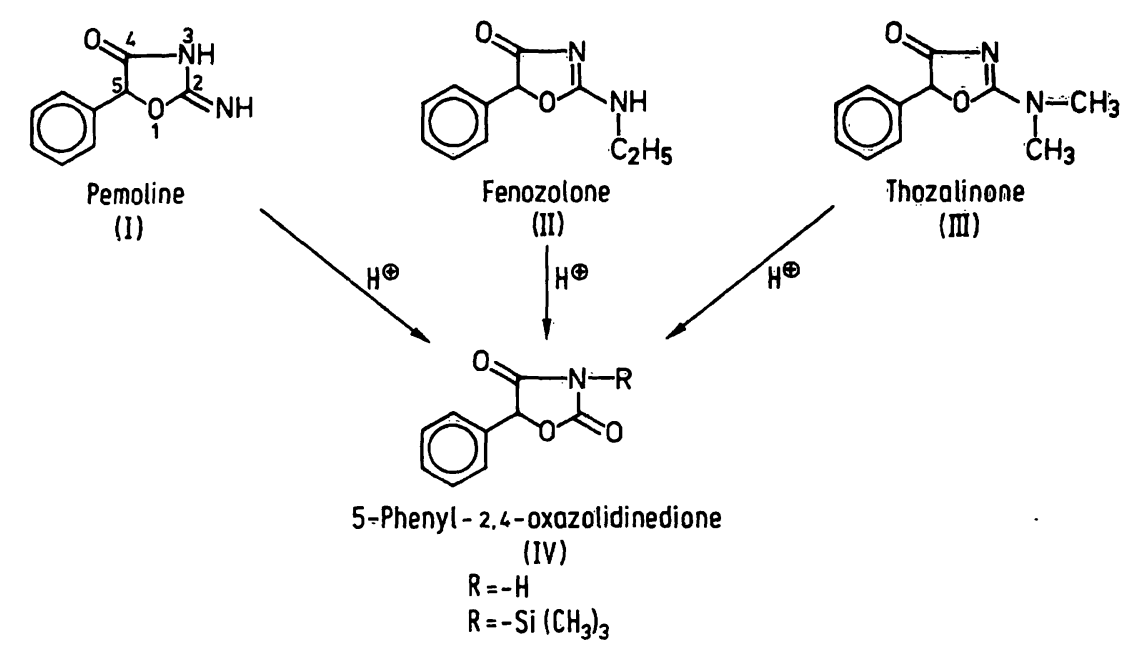

Fig. 1. Structural formulae of the investigated drugs and their common hydrolysis product 5-phenyl-2,4-oxazolidinedione (IV).

For screening purposes a rapid and sensitive TLCmethod is recommended; quantitative results can be obtained from the same extract by the proposed GC/ MS-method.

\section{Materials and Methods}

Gas chromatography/mass spectrometry

All GC/MS-analyses ${ }^{4}$ ) were performed on a Finnigan 4023 according to l.c. (17); oven temperature was $180^{\circ} \mathrm{C}$ isothermically.

Mass spectra of II and III were obtained by solid probe inlet.

\section{Thin layer chromatography}

TLC-plates $\left(\mathrm{HF}_{254}\right)$ were obtained from E. Merck, Darmstadt. Solvent system: chloroform/acetone $80 \mathrm{ml}+20 \mathrm{ml}$.

For detection "Dresslers Reagent"5) (18) is most suitable, giving bright red spots, changing to orange after $10 \mathrm{~min}$. Less than $0.5 \mu \mathrm{g}$ could easily be visualized. $R_{\mathrm{f}}$-values: $I=0.06$, II $=0.22$, III $=0.37$ and IV $=0.52$. With Dragendorffs reagent (and subsequently spraying a solution of $50 \mathrm{~g} / \mathrm{l}$ Fe(III)-chloride) only II and III were detectable.

4) See "GC/MS Assays for Abused Drugs in Body Fluids", Chapter $1+2$, by R. L. Foltz, A. F. Fentiman and R. B. Foltz, NIDA Research Monograph 32, Aug. 1980.

5) Dressler's Reagent: Solution $1=200 \mathrm{~g} / \mathrm{l}$ potassium hydroxide in methanol; Solution $2=10 \mathrm{~g} / 1 \mathrm{~m}$-dinitrobenzene in methanol.

Spray solution until plate is transparent, dry plate (hair-dryeri) then apply solution 2 .

\section{Extraction/hydrolysis}

To $5 \mathrm{ml}$ urine in a centrifuge tube $1 \mathrm{ml} 6 \mathrm{~mol} / \mathrm{l}$ hydrochloric acid was added and heated for $15 \mathrm{~min}$ in an aluminium block. at $80^{\circ} \mathrm{C}$. After adding $3 \mathrm{~g}$ of anhydrous sodium sulphate, the cooled hydrolyziate was extracted twice with $5 \mathrm{ml}$ ether. After centrifugation the organic phases were removed, collected and evaporated to dryness in an $\mathrm{N}_{2}$ stream.

\section{Derivatization}

\section{a) Silylation:}

The extraction residue was dissolved in a mixture of $500 \mu \mathrm{l}$ $\mathrm{N}$-methyl-N-trimethylsilyltrifluoracetamide and $20 \mu \mathrm{l}$ trimethylchlorosilane; the capped tube was left for half an hour at $60^{\circ} \mathrm{C}$. Then $3 \mu \mathrm{l}$ of the resulting solution were injected in the GC.

b) Alkylation:

Several alkylation procedures were tested tô obtain the desired 5-phenyl-2,4-oxazolidinedione- $\mathrm{N}$-alkyl derivative, mainly the $\mathrm{N}$-methyl derivative, according to the methods described by KováC \& Anderle (19) and Vycudilik (20), but no satisfactory results were obtained.

\section{Renal excretion studies with peimoline}

Three male, healthy human volunteers received one hour after breakfast a single dose of $30 \mathrm{mg}$ pemoline orally. The urine was collected during the following two days after administration; excretion was determined via the silylated 5-phenyl-2,4oxazolidinedione. Quantification was achieved by spiking urine samples with authentic 5-phenyl-2,4-oxxazolidinedione (concentrations ranging from 0 to $20 \mathrm{mg} / \mathrm{l}$ ) and direct compẩrison of the corresponding TLC-areas by operating the GC/MS in the chemical ionișation (CI) mode (reagent gas: iso-butane) and recording the $\mathrm{MH}^{+}$-lon at $\mathrm{m} / \mathrm{z} 250$. 
Before starting these studies, a blank urine was collected and treated in the same manner as the drug-containing samples. The coefficient of variation $(n=5)$ was about $10 \%$. Average recovery based on three determinations was about $72 \%$. Reproducibility between duplicate injections was always better than $8 \%$.

\section{Results and Discussion}

On account of their polarity, pemoline, fenozolone and thozalinone are difficult to extract from biological fluids and to analyze; for instance none of them elutes directly from the GC-column. Derivatization of the compounds as such leads to various products in changing yields; a uniform product was not attainable (1).

The cited experiments have shown that a method, based on acidic hydrolysis to the 5-phenyl-2.4-oxazolidinedione meets the requirements for a rapid and sensitive screening procedure in urine. Under the described conditions this reaction is practically complete.

For screening purposes (or if a GC/MS is not available) the presented TLC-method has its merits; this method is very selective, for no other substance in human urine reacts in the described characteristic manner with Dressler's reagent $(4,5)$ : thus positive identifications were achieved up to 24 hours after administration (of I).

If quantitative results are needed, e.g. when pharmacokinetic studies are on work, the proposed GC/MS method should be employed: this includes silylation of IV with $\mathrm{N}$-methyl-N-trimethylsilyltrifluoroacetamide, operating the GC/MS in the chemical ionisation (CI-) mode and monitoring the $\mathrm{MH}^{+}$ion at $\mathrm{m} / \mathrm{z} 250$. Silylation of IV

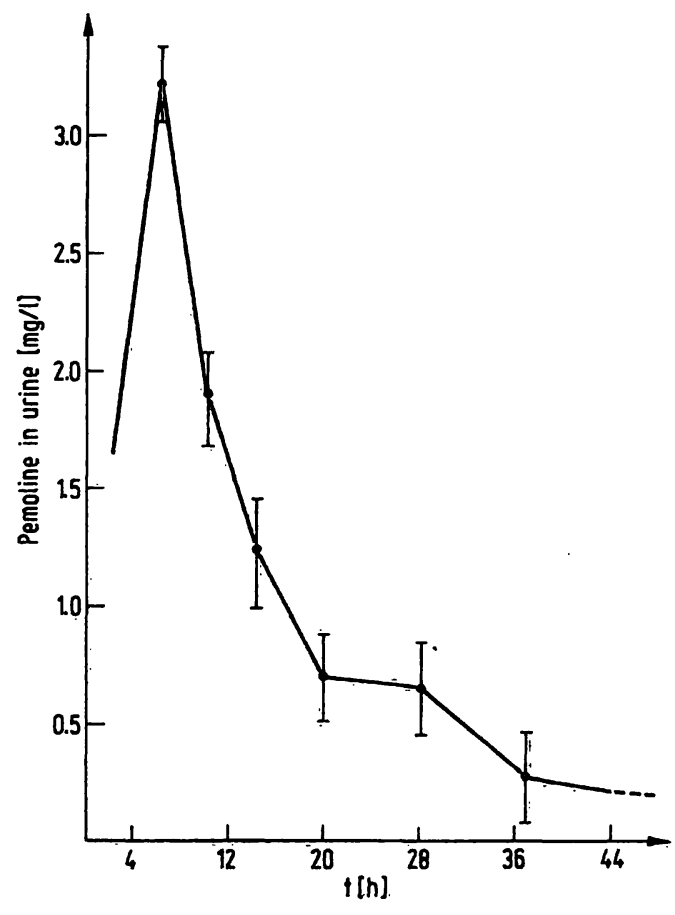

Fig. 2. Renal excretion of pemoline, determined by GC/MS via its silylated degradation-product 5-phenyl-2,4-oxazolidinedione (IV) after ingestion of $30 \mathrm{mg}$ pemoline (I). resulted in a better peak shape, lower detection limit (approx. $15 \mathrm{ng}$ absolutely) and - owing to the shorter retention time - a more rapid analysis-time with respect to the alkylation procedures cited.

To demonstrate the efficiency of the method, renal studies were performed: after ingestion of $30 \mathrm{mg}$ pemoline, concentrations between 1 and $4 \mathrm{mg} / \mathrm{l}$ were observed (fig. 2).

For completeness, the mass spectra of fenozolone and thozalinone are depicted in figures 3,4 ; the mass spectra of compounds I and IV have been reported previously $(1,2)$.

The preferred fragmentation pathway of them all is cleavage of the bonds $1 / 2$ and $4 / 5$ with or without hydrogen rearrangement (5). Which of the resulting fragments appears as a cation, depends on the ability

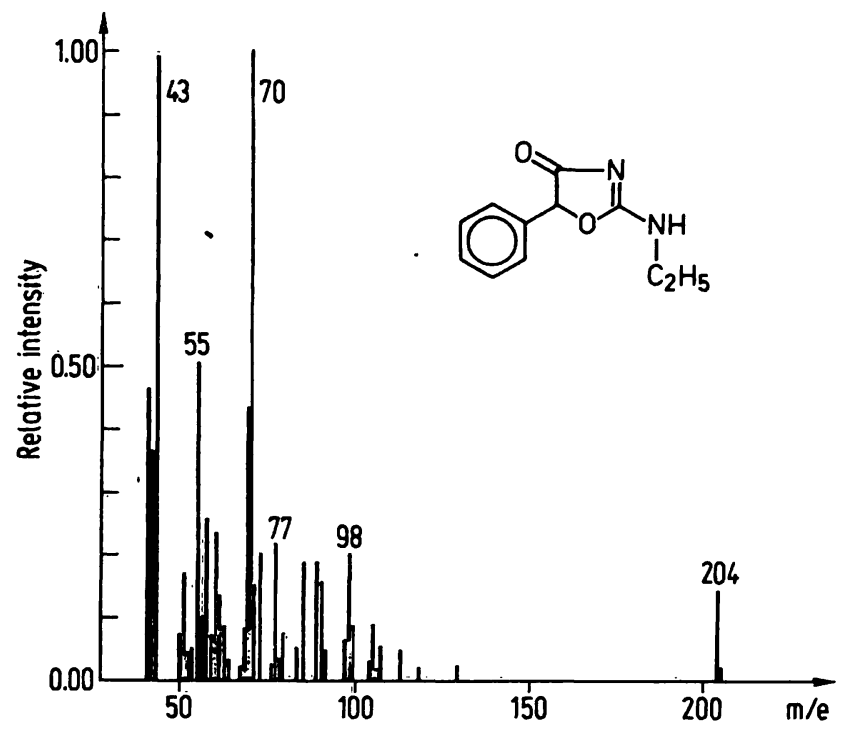

Fig. 3. Electron impact (EI) mass spectrum of fenozolone (II) by direct insertion.

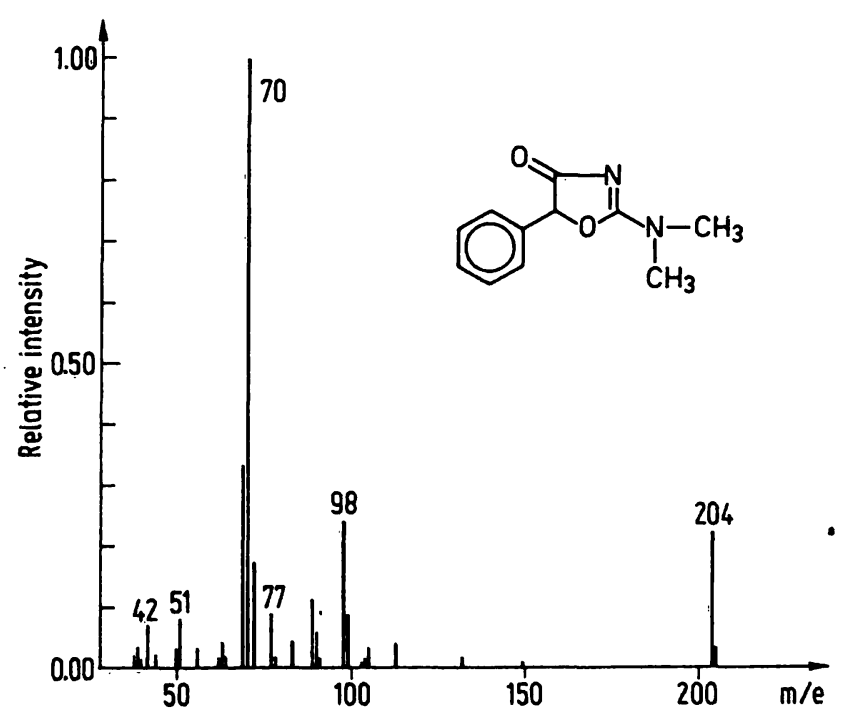

Fig. 4. Electron impact (EI) mass spectrum of thozalinone (III) by direct insertion. 
of the substituent at $\mathrm{C}-2$ to stabilize a positive charge: in the case of substance IV this happens exclusively at the fragments bearing the phenyl group $(\mathrm{m} / \mathrm{z}$ 105-107, 89 and $90,77-79)$. In contrast, in the case of substance II, this occurs for the fragments bearing the amidine group, as shown by the intensities of the ions $\mathrm{m} / \mathrm{z} 98$ and 70 . The mass spectrum of $I$ is dominated by ions containing the phenyl group, but $\mathrm{m} / \mathrm{z} 70$ is also clearly visible with a relative intensity of $35 \%$. A detailed discussion of the mass spectra of oxazolidinediones, e.g. paramethadione, primidone and phenacemide, is presented by Locock \& Coutts (21).

The electron impact (EI) mass spectrum of the N-trimethylsilyl derivative of 5-phenyl-2,4-oxazolidinedione showed an intense M-15 peak (as expected), but the trimethylsilyl group did not influence the discussed fragmentation pattern. Among fragments exceeding $\mathrm{m} / \mathrm{z} 200$, this ion $(=\mathrm{m} / \mathrm{z} 234)$ would be a good choice for selected ion monitoring, but optimum results were obtained by operating the GS/MS in the chemical ionisation (CI) mode and monitoring the quasimolecular ion $\left(\mathrm{MH}^{+}\right) \mathrm{m} / \mathrm{z} 250$, which contains over $80 \%$ of the ion current of the scan (fig. 5).

\section{References}

1. Vermeulen, N. P. E., de Roode, D. \& Breimer, D. D. (1977) J. Chromatogr. 137, 333-342.

2. van Boven, M. \& Daenens, P. (1977) J. Chromatogr. 134, $415-421$.

3. de Sio, F., Marena, C. \& Bertol, E. (1975) Med. Sport 26, 23-27.

4. Goenechea, S. \& Wagner, G. (1977) J. Chromatogr. 140, 134-136.

5. Goenechea, S., Eckhardt, G. \& Gielsdorf, W. (1978) Fresenius Z. Anal. Chem. 289, 110-111.

6. Donike, M. \& Gielsdorf, W. (1978) Z. Sportmed. 29, 4-8.

7. Traube, W. \& Ascher, R. (1913) Ber. Dtsch. Chem. Ges. 46, 2077-2084.

8. Lindberg, L. H. \& Pedersen, J. (1968) Acta Pharmacol. Suecica $5,15-22$.

9. Harnden, M. R. \& Rasmussen, R. R. (1969) J. Med. Chem. 12, 919-921.

10. Sou-Yie, C. \& Sennello, L. T. (1977) J. Chromatogr. 137, 343-350.

11. Cummins, L. M. \& Perry, J. E. (1969) J. Pharm. Sci. 58,
$762-763$.

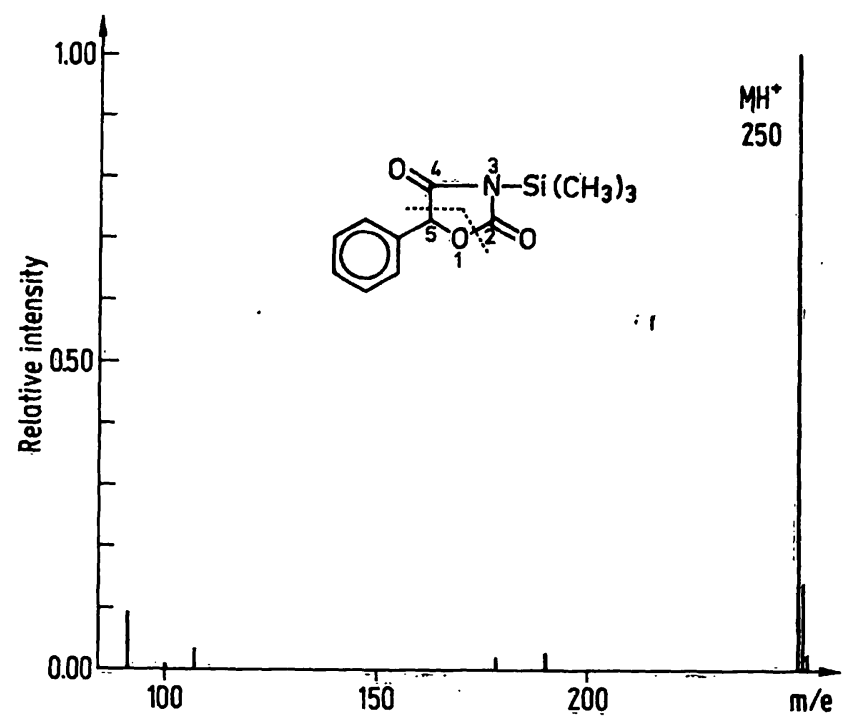

Fig. 5. Chemical ionisation (CI) mass spectrum (with isobutane) of the 5-phenyl-2,4-oxazolidinedione- $\mathrm{N}$-trimethylsilyl derivative.

Under these conditions, up to 10 samples can be analyzed within one hour.
12. Freundt, K. J. \& Schwinger, G. (1964) Arch. Toxicol. 20 , 257-262.

13. Eberhardt, H. \& Debackere, M. (1965) Z. Arzneimittelforsch. (Drug Res.) 15, 929-930.

14. Kassau, E. (1964) Dtsch. Apoth. Ztg. 104, 613-616.

15. Bister, F. \& Wolff, J. H. (1983) Z. Arnzneimittelforsch. (Drug Res.) 3, 481.

16. Cartoni, G. P. \& Natalizia, F. (1976) J. Chromatogr. 123, 474-478.

17. Gielsdorf, W. \& Toffel-Nadolny, P. (1981) J. Clin. Chem. Clin. Biochem. 19, 25-30.

18. Dressler, A. (1959) Arch. Toxicol. 17, 293-294.

19. KováC, P. \& Anderle, D. (1978) in: Derivatives for Chromatography (Blau, K. \& King, G. eds.) Heyden, London.

20. Vỵcudilik, W. (1977) Z. Rechtsmed. 80, 197-203.

21. Locock, R. A. \& Coutts, R. T. (1970) Org. Mass Spectrometr. 3, 735-745.

Dr. W. Gielsdorf

LAB Gesellschaft für pharmakologische Studien Brühlweg 23

D-7910 Neu-Ulm/Gerlenhofen 